\title{
Research advances in the diagnosis and treatment of Chiari malformations: a bibliometric analysis
}

India Rangel ( $\square$ rangel.india@mayo.edu )

Mayo Clinic Arizona https://orcid.org/0000-0003-2091-9199

Rohin Singh

Marissa D. McLelland

Armaan Dodd

Nathan A. Shlobin

Jenna H. Meyer

Miles Hudson

Oren Gottfried

\section{Research Article}

Keywords: bibliometric analysis, citations, Chiari, neurosurgery

Posted Date: February 11th, 2022

DOI: https://doi.org/10.21203/rs.3.rs-1328815/v1

License: (1) (1) This work is licensed under a Creative Commons Attribution 4.0 International License. Read Full License 


\section{Abstract}

Chiari malformation is a relatively rare condition involving herniation of the brain out of the skull and into the spinal canal. The purpose of this review was to identify top contributors to the world of Chiari research, as well as to highlight the publications which have shaped our perception of this condition.

We performed a search of the Web of Science between the years 1900 and 2021 using the terms "Chiari I malformation", "Arnold Chiari malformation", "Chiari II malformation”, "Chiari malformation type 1", and "Chiari malformation type 2". After screening for duplicates and assessing for relevance using two independent reviewers, the top 100 most frequently cited articles were collected and sorted. These articles were published between the years 1938 and 2015 and were cited 145.7 times on average, ranging from 79 to 724 citations per article. Authored by Milhorat et al., the 1999 Neurosurgery article "Chiari I Malformation Redefined: Clinical and Radiographic Findings for 364 Symptomatic Patients" received most citations (724 citations). Journal of Neurosurgery contributed the most articles to the top-100 with 21 publications. The University of California system accounted for the most articles by institution (8 of 100) and the USA was the highest contributing country (62\%).

In this study, we identified and analyzed the most cited articles on Chiari malformations to gain a better understanding of the publications contributing our knowledge of this disorder. This analysis serves both as a way of gauging the current state of research and of recognizing gaps where further research is necessary.

\section{Introduction}

A Chiari malformation is an uncommon condition in which a portion of the brain is displaced into the spinal canal. There are two distinct types of Chiari-type I involves herniation of a portion of the cerebellum and may be entirely asymptomatic, while type II often involves conditions such as myelomeningoceles, in addition to cerebellum herniation, and is typically symptomatic at birth[9]. These malformations can lead to serious neurological complications which were thought to be unavoidable outcomes until relatively recently.

Chiari I is estimated to occur in approximately 1 out of every 1,000 live births, with Chiari II being much rarer[16]. Chiari I involves herniation of the cerebellar tonsils alone and is associated with syringomyelia, while Chiari II involves the tonsils as well as the vermis and often presents with a myelomeningocele[7; 17]. Symptomatic Chiari I patients present either in early childhood with notable brainstem dysfunction or as adults with short-lived headaches, which are often associated with Valsalva-related actions such as coughing[8; 9]. The pathophysiology of Chiari malformations is still not fully understood, though there are several theories, including neural tube defects

and abnormal skull base formation[3; 4]. Though first described in 1891 by Hans Chiari, it has only been in the past few decades that there has been significant advancement in diagnosis and treatment of this condition. A radical shift in treatment has occurred since the 1970s, as surgery has assumed a larger role in treatment[9; 20]. Currently, pressure relief via bony decompression is the standard of care for malformations which require surgery[6; 18; 19].

Given the large amount of research focused on Chiari malformations, covering everything from epidemiology to outcomes, there is a risk of overlooking potentially impactful publications. Bibliometric analyses have come forward as a way to explore this high number of publications and identify the most cited works[14]. By analyzing the most impactful works since 1900, we gain insight into the progression of our understanding of Chiari and into the gaps that still exist in the current research. In summarizing these data, we hope to assist healthcare providers in choosing the best possible care for their patients and to provide a shortlist of publications detailing surgical advancements. 
Using a bibliometric analysis, we collected 100 of the top cited articles on Chiari malformations. The purpose of this review was to identify the most prominent investigators in the field of Chiari research and to summarize how our understanding has developed since the beginning of the 20th century.

\section{Methods}

\section{Search Strategy}

We performed a search in December 2021 of the Web of Science database to identify the most cited publications regarding Chiari malformation. The search terms "Chiari I malformation”, "Arnold-Chiari malformation”, "Chiari II malformation", "Chiari malformation type 1", and "Chiari malformation type 2" were used with "OR" between each topic and a date range between 1900 and 2021. The results were sorted by citation count in descending order. Publications were excluded if they included one of the above search terms in the search description and/or abstract but were not exclusively about Chiari malformations. A total of 2,970 article results were obtained from this search. Two independent reviewers (RS and MM) selected relevant articles, including only "Articles" and "Reviews" as categorized by Web of Science. Exclusion criteria included abstract publications and articles not published in English. After reviewing for duplicates, a list of the top 100 most frequently cited articles was compiled for further analysis.

\section{Data}

Characteristics of the top 100 most-cited articles cataloged included title, authors, country of origin of the authors and/or publication, publishing journal, total citations, citations per year for each article (total number of citations over the years in circulation), year of publication, and study type. The publications were divided into the following research categories: case report or series, retrospective study, cohort study, editorial, animal study, meta-analysis, literature review, survey research, epidemiology, morphometric data, prospective study, and randomized controlled trials.

\section{Bibliometric Parameters}

The following bibliometric parameters were analyzed: author's h-index (indicative of both publication count and citation count by each author),[2] the publishing journal's source-normalized impact per paper (SNIP), and SCImago Journal Rank (SJR). The h-indices for the top 10 contributing authors and the citations per year for every publication were obtained from the Web of Science. The SNIP and SJR scores for the top 5 publishing journals of the top 100 most-cited articles were retrieved from the Scopus database.[15]

\section{Results}

\section{Article Analysis}

The Web of Science database search resulted in 2,970 articles. Of these articles, the top 100 most-cited publications that met our inclusion criteria were analyzed (Supplementary Table 1). The mean number of total citations for each article was 145.9 , with a range of 79 to 724 citations per article. The publication year for these articles ranged from 1938 to 2015 . The publications were sorted by year of publication and grouped into decades. The greatest number of these publications was found to be published between the years 2000 and 2009 , with 36 of the 100 articles published in this time frame (Figure 1). The article with the highest number of citations (724 
citations), was "Chiari I Malformation Redefined: Clinical and Radiographic Findings For 364 Symptomatic Patients" by Milhorat et al.[10]. The 10 most frequently cited articles (Table 1) have a citation count ranging between 256 and 724 . 
Table 1

The Top 10 Most Cited Publications on Chiari Malformations

\begin{tabular}{|c|c|c|c|c|c|c|c|}
\hline Rank & $\begin{array}{l}\text { Total } \\
\text { Citations }\end{array}$ & First Author & Last Author & Title & Year & Journal & Country \\
\hline 1 & 724 & Milhorat, TH & Speer, MC & $\begin{array}{l}\text { Chiari I } \\
\text { Malformation } \\
\text { Redefined: } \\
\text { Clinical And } \\
\text { Radiographic } \\
\text { Findings For } 364 \\
\text { Symptomatic } \\
\text { Patients }\end{array}$ & 1999 & NEUROSURGERY & USA \\
\hline 2 & 535 & Oldfield, EH & Patronas, NJ & $\begin{array}{l}\text { Pathophysiology } \\
\text { Of } \\
\text { Syringomyelia } \\
\text { Associated With } \\
\text { Chiari I } \\
\text { Malformation Of } \\
\text { The Cerebellar } \\
\text { Tonsils - } \\
\text { Implications For } \\
\text { Diagnosis And } \\
\text { Treatment }\end{array}$ & 1994 & $\begin{array}{l}\text { JOURNAL OF } \\
\text { NEUROSURGERY }\end{array}$ & USA \\
\hline 3 & 369 & $\begin{array}{l}\text { Nishikawa, } \\
\text { M }\end{array}$ & Inoue, $\mathrm{Y}$ & $\begin{array}{l}\text { Pathogenesis Of } \\
\text { Chiari } \\
\text { Malformation: A } \\
\text { Morphometric } \\
\text { Study Of The } \\
\text { Posterior Cranial } \\
\text { Fossa }\end{array}$ & 1997 & $\begin{array}{l}\text { JOURNAL OF } \\
\text { NEUROSURGERY }\end{array}$ & Japan \\
\hline 4 & 317 & Heiss, JD & Oldfield, EH & $\begin{array}{l}\text { Elucidating The } \\
\text { Pathophysiology } \\
\text { Of } \\
\text { Syringomyelia }\end{array}$ & 1999 & $\begin{array}{l}\text { JOURNAL OF } \\
\text { NEUROSURGERY }\end{array}$ & USA \\
\hline 5 & 307 & Meadows, J & Carson, BS & $\begin{array}{l}\text { Asymptomatic } \\
\text { Chiari Type I } \\
\text { Malformations } \\
\text { Identified On } \\
\text { Magnetic } \\
\text { Resonance } \\
\text { Imaging }\end{array}$ & 2000 & $\begin{array}{l}\text { JOURNAL OF } \\
\text { NEUROSURGERY }\end{array}$ & USA \\
\hline 6 & 302 & Matsuoka, T & Koentges, G & $\begin{array}{l}\text { Neural Crest } \\
\text { Origins Of The } \\
\text { Neck And } \\
\text { Shoulder }\end{array}$ & 2005 & NATURE & England \\
\hline 7 & 291 & Elster, AD & Chen, MYM & $\begin{array}{l}\text { Chiari-i } \\
\text { Malformations - } \\
\text { Clinical And } \\
\text { Radiologic } \\
\text { Reappraisal }\end{array}$ & 1992 & RADIOLOGY & USA \\
\hline 8 & 277 & Mclone, DG & Knepper, PA & $\begin{array}{l}\text { The Cause Of } \\
\text { Chiari-ii } \\
\text { Malformation - A } \\
\text { Unified Theory }\end{array}$ & 1989 & $\begin{array}{l}\text { PEDIATRIC } \\
\text { NEUROSCIENCE }\end{array}$ & USA \\
\hline
\end{tabular}




\begin{tabular}{|c|c|c|c|c|c|c|c|}
\hline Rank & $\begin{array}{l}\text { Total } \\
\text { Citations }\end{array}$ & First Author & Last Author & Title & Year & Journal & Country \\
\hline 9 & 265 & Paul, KS & Dutton, J & $\begin{array}{l}\text { Arnold-chiari } \\
\text { Malformation - } \\
\text { Review Of } 71 \\
\text { Cases }\end{array}$ & 1983 & $\begin{array}{l}\text { JOURNAL OF } \\
\text { NEUROSURGERY }\end{array}$ & England \\
\hline 10 & 256 & $\begin{array}{l}\text { Marinpadilla, } \\
\text { M }\end{array}$ & $\begin{array}{l}\text { Marinpadilla, } \\
\text { TM }\end{array}$ & $\begin{array}{l}\text { Morphogenesis } \\
\text { Of } \\
\text { Experimentally } \\
\text { Induced Arnold- } \\
\text { chiari } \\
\text { Malformation }\end{array}$ & 1981 & $\begin{array}{l}\text { JOURNAL OF } \\
\text { THE } \\
\text { NEUROLOGICAL } \\
\text { SCIENCES }\end{array}$ & USA \\
\hline
\end{tabular}

Following the model of Bohl and Ponce, the mean number of citations per year was calculated for each article in order to make up for the advantage that older publications hold over more recent populations when analyzing impact based on total citations[1]. The 10 articles with the highest number of citations per year are displayed in Table 2. The 1999 Milhorat et al. article, Chiari I Malformation Redefined: Clinical And Radiographic Findings For 364 Symptomatic Patients, was still found to have the highest number of citations per year. Similarly, the article Pathophysiology Of Syringomyelia Associated With Chiari I Malformation Of The Cerebellar Tonsils - Implications For Diagnosis And Treatment, which had the second-highest number of citations overall, also had the secondhighest number of citations per year. 
Table 2

The Top 10 Citations Per Year on Chiari Malformations

\begin{tabular}{|c|c|c|c|c|c|c|c|}
\hline Rank & $\begin{array}{l}\text { Citations } \\
\text { Per Year }\end{array}$ & $\begin{array}{l}\text { First } \\
\text { Author }\end{array}$ & $\begin{array}{l}\text { Last } \\
\text { Author }\end{array}$ & Title & Year & Journal & Country \\
\hline 1 & 32.91 & $\begin{array}{l}\text { Milhorat, } \\
\text { TH }\end{array}$ & $\begin{array}{l}\text { Speer, } \\
\text { MC }\end{array}$ & $\begin{array}{l}\text { Chiari I Malformation } \\
\text { Redefined: Clinical } \\
\text { And Radiographic } \\
\text { Findings For } 364 \\
\text { Symptomatic } \\
\text { Patients }\end{array}$ & 1999 & NEUROSURGERY & USA \\
\hline 2 & 19.81 & $\begin{array}{l}\text { Oldfield, } \\
\mathrm{EH}\end{array}$ & $\begin{array}{l}\text { Patronas, } \\
\text { NJ }\end{array}$ & $\begin{array}{l}\text { Pathophysiology of } \\
\text { Syringomyelia } \\
\text { Associated With } \\
\text { Chiari I Malformation } \\
\text { Of The Cerebellar } \\
\text { Tonsils - Implications } \\
\text { For Diagnosis And } \\
\text { Treatment }\end{array}$ & 1994 & $\begin{array}{l}\text { JOURNAL OF } \\
\text { NEUROSURGERY }\end{array}$ & USA \\
\hline 3 & 18.88 & $\begin{array}{l}\text { Matsuoka, } \\
\text { T }\end{array}$ & $\begin{array}{l}\text { Koentges, } \\
\text { G }\end{array}$ & $\begin{array}{l}\text { Neural Crest Origins } \\
\text { Of The Neck And } \\
\text { Shoulder }\end{array}$ & 2005 & NATURE & England \\
\hline 4 & 17.5 & Goel, Atul & None & $\begin{array}{l}\text { Is Atlantoaxial } \\
\text { Instability The Cause } \\
\text { Of Chiari } \\
\text { Malformation? } \\
\text { Outcome Analysis Of } \\
65 \text { Patients Treated } \\
\text { By Atlantoaxial } \\
\text { Fixation }\end{array}$ & 2015 & $\begin{array}{l}\text { JOURNAL OF } \\
\text { NEUROSURGERY- } \\
\text { SPINE }\end{array}$ & India \\
\hline 5 & 16 & Tubbs, RS & $\begin{array}{l}\text { Oakes, } \\
\text { WJ }\end{array}$ & $\begin{array}{l}\text { Institutional } \\
\text { Experience With } 500 \\
\text { Cases Of Surgically } \\
\text { Treated Pediatric } \\
\text { Chiari Malformation } \\
\text { Type I Clinical Article }\end{array}$ & 2011 & $\begin{array}{l}\text { JOURNAL OF } \\
\text { NEUROSURGERY- } \\
\text { PEDIATRICS }\end{array}$ & USA \\
\hline 6 & 15.38 & $\begin{array}{l}\text { Nishikawa, } \\
\text { M }\end{array}$ & Inoue, $Y$ & $\begin{array}{l}\text { Pathogenesis Of } \\
\text { Chiari Malformation: } \\
\text { A Morphometric } \\
\text { Study Of The } \\
\text { Posterior Cranial } \\
\text { Fossa }\end{array}$ & 1997 & $\begin{array}{l}\text { JOURNAL OF } \\
\text { NEUROSURGERY }\end{array}$ & Japan \\
\hline 7 & 14.62 & $\begin{array}{l}\text { Meadows, } \\
\mathrm{J}\end{array}$ & $\begin{array}{l}\text { Carson, } \\
\text { BS }\end{array}$ & $\begin{array}{l}\text { Asymptomatic Chiari } \\
\text { Type I Malformations } \\
\text { Identified On } \\
\text { Magnetic Resonance } \\
\text { Imaging }\end{array}$ & 2000 & $\begin{array}{l}\text { JOURNAL OF } \\
\text { NEUROSURGERY }\end{array}$ & USA \\
\hline 8 & 14.41 & Heiss, JD & $\begin{array}{l}\text { Oldfield, } \\
\text { EH }\end{array}$ & $\begin{array}{l}\text { Elucidating The } \\
\text { Pathophysiology of } \\
\text { Syringomyelia }\end{array}$ & 1999 & $\begin{array}{l}\text { JOURNAL OF } \\
\text { NEUROSURGERY }\end{array}$ & USA \\
\hline 9 & 11.22 & Tubbs, RS & $\begin{array}{l}\text { Oakes, } \\
\text { WJ }\end{array}$ & $\begin{array}{l}\text { Surgical Experience } \\
\text { In } 130 \text { Pediatric } \\
\text { Patients With Chiari I } \\
\text { Malformations }\end{array}$ & 2003 & $\begin{array}{l}\text { JOURNAL OF } \\
\text { NEUROSURGERY }\end{array}$ & USA \\
\hline
\end{tabular}




\begin{tabular}{|llllllll|}
\hline Rank & $\begin{array}{l}\text { Citations } \\
\text { Per Year }\end{array}$ & $\begin{array}{l}\text { First } \\
\text { Author }\end{array}$ & $\begin{array}{l}\text { Last } \\
\text { Author }\end{array}$ & Title & Year & Journal & Country \\
\hline 10 & 11.17 & Aitken, LA & Wu, YW & $\begin{array}{l}\text { Chiari Type I } \\
\text { Malformation In A } \\
\text { Pediatric Population }\end{array}$ & 2009 & $\begin{array}{l}\text { PEDIATRIC } \\
\text { NEUROLOGY }\end{array}$ & USA \\
\hline
\end{tabular}

\section{Author, Institutional, and Geographic Analyses}

The top 100 most-cited publications had 356 contributing authors and the 10 most frequent authors were analyzed, regardless of their level of authorship. T.H. Milhorat had the most publications among those selected, with 7 of the 100 articles (Table 3). However, W.J. Oakes published 5 articles with an author's h-index of 42, while T.H. Milhorat had an h-index of 37 (Table 3). The University of California System was the most frequently contributing institution, accounting for 8 of the 100 most-cited articles (Table 4), while the most frequently contributing country was the USA, which accounted for $62 \%$ of these publications (Table 5 ).

Table 3

The Top 5 Contributing Authors in the Top-100 Articles

\begin{tabular}{|llll|}
\hline Rank & Author & Number of Articles & Author's h-Index \\
\hline 1 & Milhorat, TH & 7 & 37 \\
\hline 2 & Oakes, WJ & 5 & 42 \\
\hline 3 (tie) & Batzdorf, U & 4 & 32 \\
\hline 3 (tie) & Tubbs, RS & 4 & 33 \\
\hline $4($ tie) & Adzick, NS & 3 & 83 \\
\hline 4 (tie) & Berciano, J & 3 & 48 \\
\hline $4($ tie) & McLong, DG & 3 & 46 \\
\hline 4 (tie) & Nishikawa, M & 3 & 13 \\
\hline
\end{tabular}

Table 4

Top 5 Institutions Contributing to the Top-100 Articles on Chiari Malformation

\begin{tabular}{|ll|}
\hline Organizations & Number of Articles \\
\hline University of California System & 8 \\
\hline Children's Hospital of Philadelphia & 5 \\
\hline Harvard University & 5 \\
\hline University of Pennsylvania & 5 \\
\hline University of Alabama- Birmingham & 4 \\
\hline University Alabama System & 4 \\
\hline University of London & 4 \\
\hline
\end{tabular}


Table 5

Top Countries of Contribution in the Top-10o Articles on Chiari

Malformation

\begin{tabular}{|l|ll|}
\cline { 2 - 3 } & Country & Percentage (\%) \\
\hline USA & 62 \\
\hline England & 8 \\
\hline Spain & 5 \\
\hline Canada & 4 \\
\hline Germany & 4 \\
\hline Italy & 4 \\
\hline Japan & 4 \\
\hline Argentina & 2 \\
\hline India & 2 \\
\hline Norway & 2 \\
\hline France & 1 \\
\hline Sweden & 1 \\
\hline Turkey & 1 \\
\hline Anal & 9 \\
\hline
\end{tabular}

\section{Journal and Article Type Analysis}

The top 100 articles included in the review were published in 34 different journals. The top 5 of these journals, which accounted for 65 of the publications, were analyzed. Journal Of Neurosurgery had the greatest number of publications in our sample, with 21 articles, and the Neurosurgery had the second greatest number with 18 publications (Table 6). Primary research studies, case report/series, retrospective study, and cohort study on the basis of the study objective and design,[15] constituted $81 \%$ of the top 100 publications (Supplementary Table 2). 
Table 6

The Top 5 Journals Containing the Top-100 Articles on Chiari Malformation

\begin{tabular}{|lllll|}
\hline Rank & Journal & Number of Citations & SNIP & SJR \\
\hline 1 & Journal Of Neurosurgery & 21 & 2.001 & 1.693 \\
\hline 2 & Neurosurgery & 18 & 1.523 & 1.290 \\
\hline 3 & Childs Nervous System & 8 & & \\
\hline 4 & Neurology & 6 & 2.336 & 3.005 \\
\hline 5 (tie) & ACTA Neurochirurgica & 4 & n/a & 0.41 \\
\hline 5 (tie) & Archives of Neurology & 4 & n/a & n/a \\
\hline 5 (tie) & Journal of Neurosurgery Pediatrics & 4 & 1.371 & 1.076 \\
\hline Abbreviations: n/a, Not available; SNIP, source-normalized impact per paper; SJR, SCImago Journal Rank \\
\hline
\end{tabular}

\section{Discussion}

In this study, we used bibliometric analysis to produce the top-cited articles on Chiari malformations since 1900. Using this data, we reviewed how our knowledge of this condition has evolved over the past century, both in terms of diagnosis and treatment.

Published in 1938, the first high-impact work of the 20th century presents a case of Chiari which was managed surgically and adds suggestions for future operations[13]. At the time of this article's publication, Chiari was not considered a surgical problem; instead, it was a rare finding to be reported in literature. With their groundbreaking work, Penfield and Coburn introduced Chiari into the world of neurosurgery[13]; however, key publications were limited in the decades that followed, and the majority focused on anatomic features and morphogenesis rather than treatment. Though no frequently cited papers were published in the 1940s, there was a small uptick in the next two decades, with 8 articles published between 1950 and 1969. These numbers steadily increased to 7 papers in the 1970s and 9 in the 1980s. The bulk of high impact Chiari research came in between 1990 and 2009, years which contributed a total of 69 top-cited papers. It was during this time that there was a shift in the content of high impact publications, with surgical techniques flooding the literature.

After the influential Milhorat publication in 1999[10], which described radiographic and clinical findings in hundreds of patients with symptomatic Chiari I, there was an outpouring of high-impact papers. This paper, aided by several landmark publications describing the possible pathophysiology of Chiari[5; 11; 12], allowed for a new area of focus. With the characterization of Chiari malformations established in the neurosurgical community, articles focusing on treatment options came to the forefront. Between the years 2000 and 2009, over a third of the top 100 papers were published, the majority of which discussed surgical techniques and clinical outcomes.

Given the limitation that older studies have in the realm of total citations, we also focused on the mean number of citations each study received per year. This provided insight into articles which were consistently relevant over time and brought newer, less-cited publications to our attention. Though the two most cited overall articles are also the two most cited per year, the lists differ from here, with more recently published papers tending to appear higher on the most cited per year list (Table 2) than the top cited overall list (Table 1). For example, when looking at the top 10 for each category, the earliest published content for citations per year is from 1994, with 6 being published during 
or after the year 2000. The top 10 for citations overall includes only 2 papers from the 2000 s. Among the top cited overall, the most common topic was the pathophysiology of Chiari with six papers; the other four publications focused on clinical descriptions with or without radiologic supplementation. In the top cited per year category, 3 surgical experience papers took the place of pathophysiology and clinical feature publications. This demonstrates the important content shift which took place at the turn of the century.

Among the top 100 publications, the majority presented the clinical features of Chiari malformations. A subset of these discussed management of patients with Chiari, with an emphasis on imaging becoming apparent over the last few decades. Starting in the 1990s, some papers started addressing Chiari I in the pediatric population, acknowledging that the clinical features and subsequent management differed for younger patients. Articles focused on surgical techniques and outcomes, most of which appeared in the late 1990s-2000s, made up a substantial portion of the top 100 . These publications were assisted by numerous studies devoted the pathophysiology of Chiari, which both contributed to the clinical picture of the disorder and introduced new possible targets for surgical management.

The highest total citation count belonged to Milhourat et al., a publication which still receives an average of 32.9 citations per year, and is currently sitting at 724 citations overall[10]. A landmark article, it established a clinical picture of Chiari I using a prospective cohort of 364 patients who presented with symptoms. The authors addressed the pathophysiology of Chiari I, using MRI data from their participants to support the theory that the malformation arises from a defect of the para-axial mesoderm, and demonstrated a possible genetic component to the disorder using familial aggregation studies. They also determined that a volumetrically diminished posterior cranial fossa was the most consistent finding among their cohort. The most common clinical symptoms fit with this finding, most of them related to overcrowding of the hindbrain-headaches, visual changes, spinal cord disturbances, etc. In addition to being a groundbreaking piece of work in 1999, this paper holds its clinical relevance today as modern imaging techniques are resulting in higher rates of detection.

The next most cited publication, both in total citations and citation frequency, was the work of Oldfield et al., which is cited an average of 19.8 times per year and has been cited 535 times overall[12]. Published 5 years earlier in 1994, this article delves into the pathophysiology of the syringomyelia that can develop with Chiari I. Using 7 cases, the authors proposed a new mechanism, based on the pressure acting on the surface of spinal cord rather than pressure from within the cord, as previous theories suggested. The next most cited publications followed in 1997 and 1999 with similar content, studying the pathogenesis of Chiari itself[11] and the syringomyelia associated with it[5], respectively. These papers, both of which are hold a place on the top 10 cited per year, not only contributed to a better understanding of this disorder but continue to help develop treatment options for patients today.

The case report was the type of publication observed most frequently in our analysis, closely followed by retrospective studies. Despite the significant presence of Chiari in the literature over the past few centuries, review articles breaking into the top 100 were relatively limited, with only 5 total meta-analyses or literature reviews. The University of California system contributed the most articles to the top-100, with 8 total. This was followed by the Children's Hospital of Philadelphia, Harvard University, and the University of Pennsylvania, which each contributed 5 papers. The United States published the majority of the top-100 articles, many of which were published either in Neurosurgery or Journal of Neurosurgery.

Studies which use bibliometric analyses are predisposed to several limitations. The Web of Science results only went as far back as 1900, potentially excluding the work of the earliest Chiari publications, such as those of Hans 
Chiari in the 1800s. Additionally, the classification of Chiari vs. syringomyelia was unclear for many decades, leaving the possibility that some influential works were excluded for semantic reasons. Our study was limited to English articles, which could have omitted high-impact articles published in other languages. Another limitation lies in the use of citations as a unit of measurement for impact-self-citation as well as omission bias, or the exclusion of articles which do not support a given hypothesis, produce some amount of error with this system. Given the substantial history of Chiari in the world of neurological research, it is possible that impactful papers from the early 1900 s are no longer cited if the information they initially presented has become common knowledge. It is also more challenging to obtain accurate citation data on these studies.

\section{Conclusion}

We identified the most cited publications related to Chiari malformations and described the progression of our understanding of this disorder. This bibliometric analysis can assist in choosing the best treatment options for patients and in determining the course of future research.

\section{Abbreviations}

SJR, SCImago Journal Rank; SNIP, source-normalized impact per paper

\section{Declarations}

\section{STATEMENTS AND DECLARATIONS}

FUNDING: None.

COMPETING INTERESTS: The authors have no financial or non-financial interests related to this work to disclose.

AVAILABILITY OF DATA AND MATERIAL: The data used in this study can be made available upon request.

CODE AVAILABILITY: N/A

ETHICS APPROVAL: N/A

CONSENT TO PARTICIPATE: N/A

CONSENT FOR PUBLICATION: N/A

AUTHOR CONTRIBUTIONS: All authors contributed to the study conception and design.

Conception and Design: IR, RS, MM

Acquisition of Data: RS, MM

Analysis and Interpretation of Data: IR, RS, MM

Drafting the Article: IR, RS, MM, AD, NS

Critically Revising the Article: IR, RS, MM, AD, NS, JM, MH, OG 
Reviewed Final Version of the Manuscript and Approved it for Submission: IR, RS, MM, AD, NS, JM, MH, OG

Statistical Analysis: N/A

Administrative/Technical/Material Support: JM, MH, OG

Study Supervision: JM, MH, OG

\section{References}

1. Bohl MA, Ponce FA (2017) Assessing the Relevancy of Highly Cited Works in Neurosurgery. Part I: The 100 Most Relevant Papers in Neurosurgical Journals. World Neurosurg 104:927-938.

doi:10.1016/j.wneu.2017.03.149

2. Choudhri AF, Siddiqui A, Khan NR, Cohen HL (2015) Understanding Bibliometric Parameters and Analysis. Radiographics 35(3):736-746. doi:10.1148/rg.2015140036

3. Dlouhy BJ, Dawson JD, Menezes AH (2017) Intradural pathology and pathophysiology associated with Chiari I malformation in children and adults with and without syringomyelia. J Neurosurg Pediatr 20(6):526-541. doi:10.3171/2017.7.Peds17224

4. Goel A (2015) Is atlantoaxial instability the cause of Chiari malformation? Outcome analysis of 65 patients treated by atlantoaxial fixation. J Neurosurg Spine 22(2):116-127. doi:10.3171/2014.10.Spine14176

5. Heiss JD, Patronas N, DeVroom HL, Shawker T, Ennis R, Kammerer W, Oldfield EH (1999) Elucidating the pathophysiology of syringomyelia. J Neurosurg 91(4):553-562. doi:10.3171/jns.1999.91.4.0553

6. Klekamp J (2012) Surgical treatment of Chiari I malformation-analysis of intraoperative findings, complications, and outcome for 371 foramen magnum decompressions. Neurosurgery, 71(2), 365-380; discussion 380. doi:10.1227/NEU.0b013e31825c3426

7. Kuhn J, Emmady PD (2022) Chiari II Malformation. StatPearls. StatPearls Publishing, Treasure Island (FL)

8. Copyright (2022) (C) StatPearls Publishing LLC

9. Langridge B, Phillips E, Choi D (2017) Chiari Malformation Type 1: A Systematic Review of Natural History and Conservative Management. World Neurosurg 104:213-219. doi:10.1016/j.wneu.2017.04.082

10. McClugage SG, Oakes WJ (2019) The Chiari I malformation. J Neurosurg Pediatr 24(3):217-226. doi:10.3171/2019.5.Peds18382

11. Milhorat TH, Chou MW, Trinidad EM, Kula RW, Mandell M, Wolpert C, Speer MC (1999) Chiari I malformation redefined: clinical and radiographic findings for 364 symptomatic patients. Neurosurgery 44(5):1005-1017. doi:10.1097/00006123-199905000-00042

12. Nishikawa M, Sakamoto H, Hakuba A, Nakanishi N, Inoue $Y$ (1997) Pathogenesis of Chiari malformation: a morphometric study of the posterior cranial fossa. J Neurosurg 86(1):40-47. doi:10.3171/jns.1997.86.1.0040

13. Oldfield EH, Muraszko K, Shawker TH, Patronas NJ (1994) Pathophysiology of syringomyelia associated with Chiari I malformation of the cerebellar tonsils. Implications for diagnosis and treatment. J Neurosurg 80(1):315. doi:10.3171/jns.1994.80.1.0003

14. Penfield W, Coburn DF (1938) ARNOLD-CHIARI MALFORMATION AND ITS OPERATIVE TREATMENT. Archives of Neurology \& Psychiatry 40(2):328-336. doi:10.1001/archneurpsyc.1938.02270080112007

15. Reddy VP, Singh R, McLelland MD, Barpujari A, Catapano JS, Srinivasan VM, Lawton MT (2022) Bibliometric analysis of the extracranial-intracranial bypass literature. World Neurosurg. doi:10.1016/j.wneu.2022.01.095 
16. Röhrig B, du Prel JB, Wachtlin D, Blettner M (2009) Types of study in medical research: part 3 of a series on evaluation of scientific publications. Dtsch Arztebl Int 106(15):262-268. doi:10.3238/arztebl.2009.0262

17. Sadler B, Kuensting T, Strahle J, Park TS, Smyth M, Limbrick DD, Gurnett CA (2020) Prevalence and Impact of Underlying Diagnosis and Comorbidities on Chiari 1 Malformation. Pediatr Neurol 106:32-37. doi:10.1016/j.pediatrneurol.2019.12.005

18. Talamonti G, Marcati E, Mastino L, Meccariello G, Picano M, Aliberti D, G (2020) Surgical management of Chiari malformation type II. Childs Nerv Syst 36(8):1621-1634. doi:10.1007/s00381-020-04675-7

19. Tubbs RS, Beckman J, Naftel RP, Chern JJ, Wellons JC 3, Rozzelle CJ, Oakes WJ (2011) Institutional experience with 500 cases of surgically treated pediatric Chiari malformation Type I. J Neurosurg Pediatr 7(3):248-256. doi:10.3171/2010.12.Peds10379

20. Tubbs RS, McGirt MJ, Oakes WJ (2003) Surgical experience in 130 pediatric patients with Chiari I malformations. J Neurosurg 99(2):291-296. doi:10.3171/jns.2003.99.2.0291

21. Varacallo JAHCATM (2021) Sep 13 2021). Arnold Chiari Malformation. Retrieved from https://www.ncbi.nlm.nih.gov/books/NBK431076/

\section{Figures}

\section{Publication on Chiari Malformation Per 10 Years}

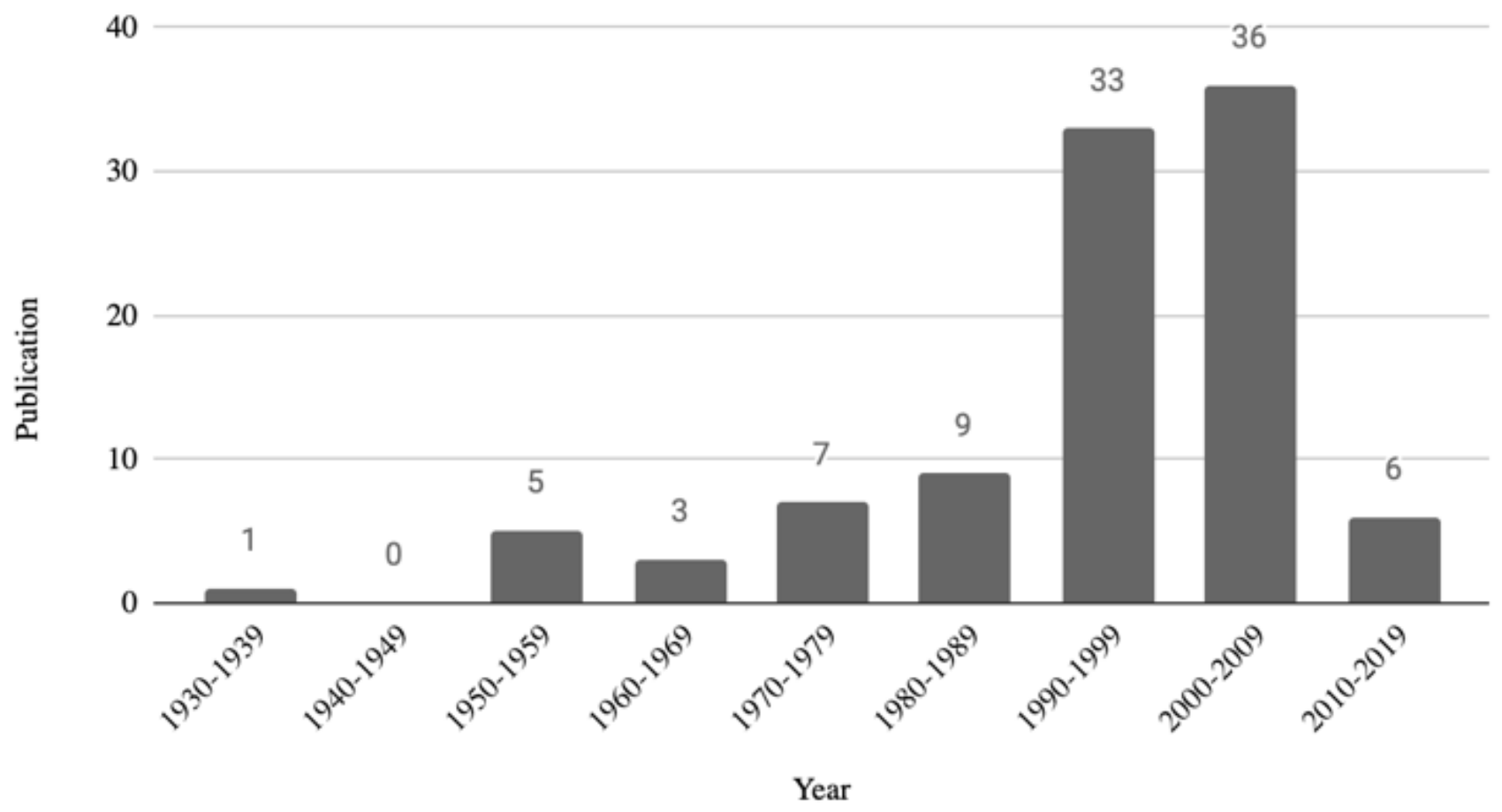

\section{Figure 1}

\section{Publication on Chiari Malformation Per 10 Years}

The number of publications from the top 100 most frequently cited articles per 10 years, between 1930 and 2019 . 


\section{Supplementary Files}

This is a list of supplementary files associated with this preprint. Click to download.

- chiarisupplement.docx 